\begin{tabular}{|lcl|}
\hline & Uniqbu Journal of Social Sciences (UJSS) \\
\hline Volume: 2 & Nomor 1, April 2021 Halaman 10-21 \\
\hline
\end{tabular}

\title{
COUNSELOR RELIGIOUS UNDERSTANDING IN IMPLEMENTATION OF EDUCATION MODERATION FOR NON-CIVIL SERVANTS
}

\author{
(Pemahaman Counselor Agama dalam Pelaksanaan Moderasi Pendidikan Bagi Non-PNS) \\ Hanafi Pelu \& Muh. Zainal Hasyim \\ Kantor Balai Diklat Agama Provinsi Maluku, Indonesia \\ Email: hanafisilawane@gmail.com
}

(Received 06 February; Revised 03 March; Accepted 04 March 2021)

\begin{abstract}
Religious counselor is the government spearhead in the regional agency, the occurrence of conflict, terrorism, radicalism, and blaming each other. Thus technological developments make the community contaminated with these developments. This paper aims to describe the role of instructors in attempting these problems. Nowadays, radical threats are widespread in Indonesian society, which is carried out by groups of radicalism, fundamentalism, extremists, and others. Radicalism act always causing unpleasant, can also cause widespread conflict, even lead to a series of acts of terror, bombing in several areas. This kind of violence must be prevented as early as possible.

Keywords: the education of Moderation, Training, religious counselor

\section{Abstrak}

Penyuluh agama merupakan ujung tombak pemerintah dalam instansi daerah, terjadinya konflik, terorisme, radikalisme dan saling menyalahkan, sehingga perkembangan teknologi membuat masyarakat terkontaminasi dengan perkembangan tersebut. Makalah ini bertujuan untuk mendeskripsikan peran instruktur untuk mencoba permasalahan tersebut. Ancaman radikal saat ini sedang meluas di masyarakat Indonesia, yang dilakukan oleh kelompok radikalisme, fundamentalisme, ekstrimis dan lain-lain. Tindakan radikalisme selalu menimbulkan ketidaknyamanan, dapat pula menimbulkan konflik yang meluas, bahkan berujung pada serangkaian aksi teror, pemboman di beberapa daerah. Kekerasan semacam ini harus dicegah sedini mungkin.

Kata Kunci: pendidikan moderasi, pelatihan, konselor agama
\end{abstract}

\section{INTRODUCTION}

Religious Moderation has recently become the main focus of the Ministry of Religion Affairs, even becoming one of the three cores that become the Ministry of Religion's spirit today. That is caused of religious Moderation has a high degree of relevance and urgency amid spiritual life in Indonesia. Religious Moderation can answer the various religious problems and global civilization, and it's the right time for the moderate generation to take more aggressive steps (Amri et al., 2018).
Moderation arises because of plurality. Thus religious Moderation is considered as a proper perspective in plural religious life. So, if there are groups of radicals, extremists, or puritans who speak loudly accompanied by acts of violence, then moderate groups must speak louder accompanied by acts of peace.

The concept of Moderation (wasathiyyah) is considered to ward off people so that they do not slip up on radical and extreme understandings. Historically groups that practiced radical and extreme 
performance, mostly accompanied by acts of violence in the name of jihad.

Planting an understanding of the concept of Moderation needs to be done early on to the younger generation. It is intended that young people have an inclusive religious attitude. So that if we are in a multicultural and pluralistic religious society, we can respect and respect the differences and position ourselves wisely in social interactions amid the community.

The vision of Islamic Moderation that needs to be instilled in Indonesia's young generation includes: (a) tolerance (tasamuh), which is recognizing and respecting differences, both in religious and social aspects, (b) taking the middle ground (tawassuth), for example; not overdoing and not overdoing reduce religious teachings, (c) balance (tawazun), namely the understanding and practice of religion in a balanced way, (d) straight and firm (i'tidal) that is keeping things in place, (e) applying a tolerant attitude, being careful in dropping the verdict infidels and heretics, (f) creating an inclusive (open) dialogue space both with internal groups or internal streams in Islam and with various non-Islamic religious leaders, (g) egalitarian, for example; not discriminating against others due to differences in beliefs or religions and tradition, (h) deliberation, that is, every problem is solved by contemplation to reach consensus with the principle of placing benefit above all.

Based on this momentum, ICRS and the Indonesian Ministry of Religion held an International Symposium on Religious Life (ISRL) in Yogyakarta, 6-9 November 2018. ISRL is a program carried out every two years and organized by the Indonesian Ministry of Religion. This year the ISRL committee invited speakers and presenters of papers from various countries such as Japan, Pakistan, Malaysia, Australia, the United States, Switzerland, Nigeria, Singapore, and Macedonia.
The International Symposium on Religious Life (ISRL 2018) was inaugurated by the Indonesian Minister of Religion, Drs. H. Lukman Hakim Saifuddin. In his remarks, he said that we should encourage the formation of the transmission of religious knowledge through cultural media products so that the development of religion and culture could go hand in hand. Negotiating religion with culture does not mean we give up the basic principles of belief in every religion in the name of culture. Likewise, reconciling culture and religion is not always the same as limiting creativity and cultural expression. Both cultural and religious activities must develop and live together in harmony and living together to preserve the unity of a highly pluralistic and multicultural Indonesian society. He also stressed that several speakers at this symposium would present and discuss research findings on the context of the relationship between religion and culture. "I believe that these topics undoubtedly address the realization of religious and cultural relations empirically, both in the context of religious life in Indonesia, Southeast Asia, and Asia and even in the context of religious communities throughout the world. Part of the speaker uses many approaches ranging from sociology, anthropology, classical Islam, comparative religion, contemporary Islamic studies to philanthropy and others ".

Many religious moderates have taken the clear primary path of pluralism, declaring all religions' same validity. Still, in doing so, they neglect to pay attention to their irreplaceable sectarian truth claims. As long as a Christian believes that only his baptized brothers will be saved on Judgment Day, he cannot "respect" others' beliefs because he knows that the fires of hell have been ignited by these ideas and awaits his adherents now.

Muslims and Jews generally take the same arrogant view of their efforts and have spent thousands of years eagerly repeating 
other religions' mistakes. It should not need to be said that these rival belief systems are all equally uncontaminated by evidence.

Based on the title explanation in the background above, the formulation of the problem in this study is; Are religious instructors able to understand moderation education?

Based on the above problem formulation, the purpose of this study is to explain whether religious instructors can understand moderation education.

The benefits of the research in this study are to increase the understanding of religion towards religious people in Indonesia so that they have an awareness that practicing religious teachings is essentially maintaining Indonesian's because Indonesia is a religious and religious country, not secular, especially to spiritual counselors as pioneers of the government's extension in the regions.

\section{THEORETICAL REVIEW Training}

Education and training create an environment where employees can acquire or learn specific attitudes, abilities, skills, knowledge, and behavior related to work. The education and training program is designed to get good quality human resources and compete in the market.

Wasti Sumarno (1990: 75) said that education is a learning process that produces personal well-being experiences, both outward and inward. Training is the process, techniques, and teaching-learning methods to transfer knowledge from one person to another according to predetermined standards. Meanwhile, R.A. Plant and R.J. Ryan (1994) states that Training (Training) includes the development of various information to individuals or groups to get a variety of new information.

John V. Chelsom put forward another definition of "training" (1997), namely, a learning process involving many achievements, skills, concepts, and rules or behaviors to improve employee performance. According to Sikula (in Martoyo, 1998: 60), the purpose of the training is as a form of human resource development which includes:

Productivity, (2) Quality, (3) Human Resources Planning, (4) Morale, (5) Indirect compensation, (6) Health and Safety, (7) Obsolescence Prevent, and (8) Personal Growth. In organizing a training program, at least four essential components need to be considered because they will determine the training implementation's effectiveness. The four elements are referred to, namely: (1) aspects of the method, (2) aspects of the instructor, (3) aspects of the curriculum, and (4) aspects of the facility.

Besides, it is necessary to understand Education Management and Coaching (Training). In analyzing the management of education and training needs to be distinguished between (1) Management of education and training personnel in the study of educational administration; (2) Elements of training management; and (3) Training Needs Analysis.

Regarding the management of Education and Training personnel in the study of education administration, it is said that education management is the study of how to manage existing resources to achieve a predetermined goal. The education management paradigm can be seen from a macro and micro review with a specific field of activity, according to the educational organization's characteristics. In this case, Engkoswara (2002: 9) classifies the three ranges of educational management. Macro examines the intact relationship between the hue of life tendencies with the quality of Indonesian human independence and the provisions of equipping in an education system.

As the focus of this research, the education and management reform policy can be positioned in the HR management constellation, which is one of the areas of education administration studies (Caiden \& 
Siedentopof, 1982). According to Religious Ministry Role of Indonesia Number 43 of 2016 concerning Management Training Information System at the Ministry of Religion in Chapter I article 1 paragraph 2 that; education and training from now on referred to as training is the organization of learning and training in the framework of developing employee competencies following the requirements of their respective positions at the Ministry of Religion.

Training Education is an institution to implement the apparatus development system that forms employees to have integrity, are professional, innovative, are responsible, and exemplary about their duties and obligations (Amri et al., 2020).

Based on Religious Ministry Role of Indonesia Number 59 of 2015 concerning the Organizational Structure of the Religious Training Center that the Makassar Training and education has functioned as follow: Task; Carry out Education and Training of Administrative and Technical Staff of Education and Religion in the Work Areas of the Ministry of Religion of the Provinces of South Sulawesi, West Sulawesi, and Southeast Sulawesi.

Function; Formulation of Vision, Mission, and Policy of the Religious Training Center; Organization of Administrative Staff Training and Religious Technical Training Services in the field of Religious Education and Training; Preparation and Presentation of reports on the results of the implementation of the Makassar Religious Training Center;

Coordination and development of partnerships with organizational units / work units within the Ministry of Religion and Local Government and Universities and other relevant institutions.

Based on the explanation of Religious Ministry Role of Indonesia, the Training and Education Agency has a duty and function to carry out the preparation and implementation of programs, Academic
Activities, Participation and Means of Structural Training, Leadership Training, Functional Training, and Administrative Technical Training.

Based on the explanation above, the training that will be carried out must be in accordance with the standards and quality of training development so that it is prestigious in the world of Education and Training.

Besides, according to Religious Ministry Role of Indonesia RI number 75 of 2015 concerning Implementation of Employee Education and Training at the Ministry of Religion in Chapter I article 1 paragraph 1, the purpose is; Education and Training, from now on referred to as training, is the implementation of learning and training in the context of developing employee competencies following the requirements of their respective positions at the Ministry of Religion, which is carried out at least 40 (forty) hours of study, with the duration of each study hour being 45 (forty-five) minute.

\section{Religious Consular}

In terms of the word consular comes from the word "torch," which means goods used to illuminate (usually made from dried coconut leaves or resin) "torch."

In general terms, counseling is one part of social science that studies the systems and processes of change in individuals and society so that changes can be realized better as expected (Setiana. L. 2005). Counseling can also be seen as a form of education for adults. In his book, A.W. Van Den Ban et al. (1999) wrote that counseling is the involvement of a person to communicate information consciously to help each other give their opinions to make the right decision.

With counseling, it is expected that an increase in knowledge, skills, and attitudes. Knowledge is said to increase when there is a change from not knowing to know and who already knows to know better. Skills are said to increase when there is a change from being unable to do a useful 
job. Attitude is said to increase if there is a change from those who don't want to be willing to take advantage of the opportunities created. (Ibrahim, et.al, 2003: $1-2)$.

Religious instructors according to the Qur'an Surah Ali-Imran / 3: 104;

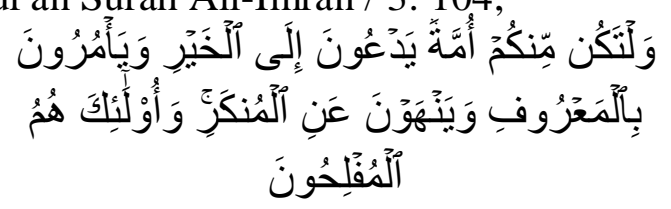

The meaning: "And let there be among you a group of people who cry out to the good, command the righteous and prevent the evil, they are the lucky ones.

As stated in the Decree of the Minister of Religion of the Republic of Indonesia number 79 of 1985 and Decree of the Minister of Religion of the Republic of Indonesia Number 164 of 1996, The Religious Instructor is a guide of religious communities in the framework of mental, moral and devotion to God Almighty. The instructor of Islam is a guide of Muslims in mental, ethical, and commitment to the Almighty God. It provides understanding and elaboration on all aspects of development through religious language.

Religious counselor in Indonesia in its historical development was first carried out by religious leaders' namely good people, preachers, clerics, and clerics who delivered directly religious lectures to the community. Before Indonesia's independence, religious education could be said to be a hidden movement, and this statement was based on the fact that religious scholars or religious leaders at this time were considered a significant threat by the colonizers because in addition to preaching about their religious teachings they also motivated their congregations to Indonesia Independence Day.

\section{Education of Moderation}

The term moderation, and the opposite of extremism and radicalism, has become very popular in recent years.
Because of his tolerance in almost all state leaders' speeches, including King Salman's address at the Indonesian Parliament booth, he also repeated the words many times.

The moderation of Islam in Arabic is called al-Wasathiyyah al-Islamiyyah. AlQaradawi mentions several vocabularies similar in meaning to him, including the Katanic Tawazun, I'tidal, Ta'adul, and Istiqamah. While in English as Islamic Moderation. Islamic Moderation is a view or attitude that always tries to take the middle position of two opposing and excessive perspectives. One of the two attitudes meant does not dominate in one's mind and mood. In other words, a moderate Muslim is a Muslim who gives each value or aspect opposite a specific portion not more than the proper amount. Because human-anyone cannot free themselves from the influence and bias of the impact of tradition, mind, family, age, and place, Al-Qaradawi cannot represent or offer full Moderation in the real world. Only Allah can do that (Yusuf alQaradhawi, 2011: 13).

Every believer has correctly understood that radical attitudes are not justified. So far, the accusation against religious radicalism is only towards Islam. While in essence, religious radicalism is not only in the Islamic world but also in other religions.

In a fragmented multicultural world, religious values that uphold the spirit of peace and harmony must be promoted and implemented to maintain unity among people to avoid chaos and violent conflict. Debate and discussion related to religiosity must always be done so that there will be many new concepts that can strengthen religiosity as the glue of social cohesion in society.

Islamic Moderation is an awareness to nurture tradition and cultivate friendly Islamic ideas. In other terms, the concept of Islamic Moderation is one option for caring for Indonesian diversity without having to uproot existing traditions and culture. 
Islamic Moderation is undoubtedly not compartmentalization of Islam, nor is it merely the name of a group, but Islam is moderate itself. This is in line with al-Qur'an (al-Baqarah: 143), which refers to Muslims as middle people (ummatan washatan). Moderate Islam adheres to the values of tawasuth, tawazun, and tasamuh; between the two extreme poles: Right and Left.

Allah Almighty says in Holy Qur'an, surah Al-Baqarah, 143;

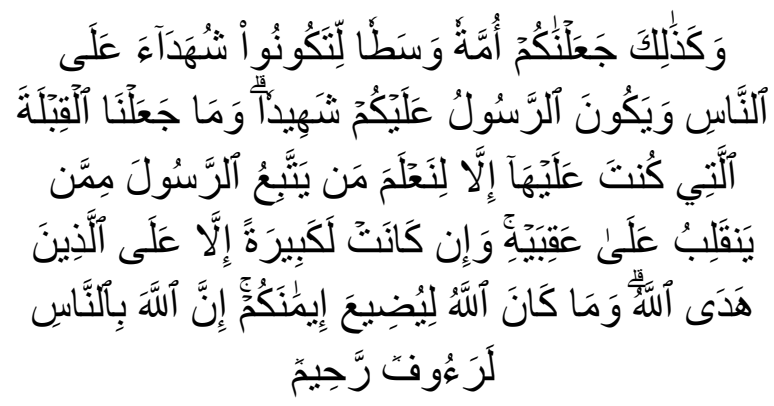

The meaning of that surah; And so (also) we have made you (Muslims), a just and chosen people so that you can be a witness to man's (deeds) and that the Apostle (Muhammad) will be your witness (doing). And we did not set the qibla that became your Qibla (now) but so that we knew (so that it was real) who followed the Apostle and who defected. And indeed (the transfer of the Qibla) feels very heavy, except for those Allah has instructed, and Allah will not waste your faith. Indeed Allah is Most Gracious, Most Merciful to humans.

In other version in holly Qur'an. Allah SWT says in Surah Al-Hujarat verse 13 ;

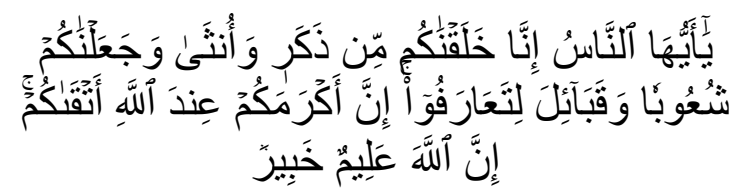

The meaning of that surah; All people, indeed we created you from a man and a woman and made you nation and tribe so that you knew each other. Undoubtedly the noblest of you in the sight of Allah is the most pious among you. Indeed Allah is AllKnowing, All-Knowing everything of you.
According to the thematic commentary book published by the Central Bureau of the Qur'an Affairs Research and Development and Educational Training Agency, the Ministry of Religious Affairs with the title of his book Islamic Moderatism and its Role in Empowering Harmony within the Society revealed that the meaning of the word Moderation comes from referees or referees, besides that it is also mentioned with the phrase al-wazn and al-adl in the book shows that these words are repeated in the Qur'an 28 times.

\section{RESEARCH METHOD}

The research method is a way to get data and information. According to Sugiono, 2009: 21, the research method is the procedure for how research is carried out. The method used in this research is qualitative research, where researchers will submit data by describing sentences.

According to Bodgan and Taylor in Sutrisno Hadi, 2009: 21, revealing qualitative research is a research procedure that produces descriptive data in the form of written or oral words from people and behavior observed.

\section{Research Approach}

The research approach used by researchers is descriptive. Where the descriptive approach only describes the phenomenon, symptoms, events, and events that happened.

According to Widi Novianto, 2016: 10 , the descriptive approach aims to describe the characteristics or individual characteristics, a particular condition, symptom, or group accurately, at a time or to see a specific relationship between a sign and other symptoms in society.

\section{Place and time of research}

Researchers will conduct this research at Makassar Religious Education and Training Center, where the researchers work as a trainer so that it is easy to retrieve and obtain data. 
Researchers will research following the implementation schedule of Islamic Education Extension Training, namely in July-August 2019.

\section{The technique of Data collection}

Data collection is essential activity for research activities because data collection will determine the success or failure. Meanwhile, according to Arikunto, 2002: 136, those data collection techniques consist of observation, interviews, and documentation.

Observation, data collection techniques by making direct observations on the object of study. According to Hasan (2002: 86), observation is the selection, alteration, recording, and coding of a series of behaviors and atmosphere regarding the organization, following empirical goals.

Interviews, data collection techniques by asking questions directly by the interviewer to the respondent, and respondents' answers recorded or recorded (Hasan, 2002: 85).

Study of Documents, the process of finding data concerning matters or variables in the form of notes, transcripts, books, newspapers, magazines, inscriptions, minutes of meetings, agendas, and et cetera.

\section{Instruments of Data Collection}

The instrument in this study was the researcher itself as a key instrument. According to Asropi, 2016: 8, researchers have the freedom to choose what forms of data are needed.

\section{Data analysis technique}

In this study, the types and sources of data used are:

\section{Primary Data}

According to Sumadi Suryabrata (2008: 82), primary data is data obtained or collected directly in the field by the person doing the research or concerned who needs it. Primary data can be obtained from informant sources, namely individuals or individuals, such as interviews conducted by researchers. Preliminary data include; Note of interviews, Note observations, and Data of informants.

Secondary Data

Secondary data is data obtained or collected by people who research existing sources (Hasan, 2002: 58). This data is used to support the preliminary information that has been received, namely from library materials, literature, previous research, books, and others.

\section{RESULTS AND DISCUSSION Training}

Organizing the activities or the training required three elements, namely, inputs, processes, and outcomes, to measure the training's success. Besides, three factors are considered the main ones in implementing the training: facilities, participants and trainers, educators, or lecturers.

In reality, in organizing the education and training program, teachers/lecturers are often not involved in the administration; for example, in determining teaching staff from outside, which is referred to as experts, so that the space of trainers is limited. In the learning process, educators/trainers involved in teaching should have a religious education background (trainers and have followed Trainers certificate training.

In supporting the learning process and the training participants' feel comfortable learning, the organizers need to prepare facilities and infrastructure to keep the learning process.

\section{Religious Counselors}

Religious Instructors are those who carry out the duties and responsibilities of the government in the regions. Thus they were assigned by the local Ministry of Religion to take part in the training. Religious Instructors who participate in the Education and Training program have passed the selection process in their respective regions with academic and religious qualifications. Besides, the Education and Training program participants 
who were included in the Education and Training came from Islamic boarding schools, and even as leaders of Islamic boarding schools, there were also some participants of Religious Education and Training who had academic backgrounds from general education.

\section{Moderation Education}

Moderation education is a major government program in the current president of a government that must be followed up in both vertically and autonomous ministries. The Ministry of Religion is vertical, specifically at the Religious Training Centers throughout Indonesia, to implement the Religious Moderation Training (a modification of the Religious Extension Training). Moderation education directs training participants and, more specifically, the teaching staff to be moderate in thinking and acting, both in the learning process in the classroom and everyday life in the Makassar Religious Training Center area.

The process of organizing Education and Training which is carried out at Makassar Religious Education and Training Center must involve all elements, not only inputs, processes, outcomes and participants, facilities and staff of lecturers or teachers, but the selection process in organizing such training, for example; certificates as supporting elements for the organizing committee, certifications, academic degrees, office experience, ranks owned by trainers. Therefore, as the person in charge of activities, it should carry out a preparatory meeting conducted by the organizers involving trainers, head of the sub-division of Administration, section and inviting external workers who are considered experts two (2) weeks before the education by distributing teaching assignments and attach a schedule, so that teaching staff or lecturers make preparations by making teaching materials, broadcast material, syllabi, and lesson plans.

Otherwise, organizers and implementers of activities must always involve trainers or lecturers in the opening and closing of the training so that the spirit and togetherness between all elements in Religious Education and Training run as well as possible.

According to Kirkpatrick, an expert of training and development evaluation expert, training is a common way by institutions, institutes, or companies to improve participants' competencies, attitudes, and knowledge. The training is conducted to increase individual performance, and the end is sustainable corporate performance within an organization. Furthermore, Kirkpatrick distributed the Four Levels of Training Evaluation so that in the implementation of the training as expected, namely;

Reaction

At this level, the success of a training can be evaluated from the trainee's reaction or response. Participants' interest and activeness in practice is an indication that participants can attend the training with enthusiasm and enthusiasm.

\section{Learning Evaluation}

Kirkpatrick (1998: 20) suggests "learning can be defined as extend to the participant change attitudes, improve knowledge, and increase skills as a result of attending the program".

\section{Behavior}

Evaluation of level 3 training is more focused on evaluating employee training from aspects of behavior change. If at level 2, training evaluation only emphasizes changes in attitude (internal), at level 3, evaluation will assess whether after attending the training participants experience behavioral changes that have an impact on performance.

\section{Evaluation of Results}

Evaluation of Training at level 4 emphasizes the final results after attending the training. The final result, in this case, can be tangible performance indicators such as increased productivity, increased profits, decreased costs, decreased error rates, 
increased quality, and decreased customer complaints.

\section{Religious Counselors}

Religious Instructors, predominantly Islamic Religious Instructors in their fostered areas, are considered capable of scientific knowledge, knowledge, and skills in carrying out their duties. Religious Instructors are also allowed to participate in Education and Training to improve their quality and experience so that Religious Instructors are familiar with their duties and tagging responsibilities.

Religious instructors are expected to carry out their duties following educational background, experience, and quality of coaching, so those spiritual counselors are not seen and as usual. According to Kgs. H. M. Daud, an Islamic instructor plays a role in developing Islamic society. The indications appear in community development activities, which include foster groups, methods, and materials. Counseling is done by transforming religious knowledge with lecture methods and practices of worship. The public is expected to know and realize the importance of practicing Islamic teachings in everyday life. The pattern of Islamic community development is carried out in stages, among others, exploratory, to create conditions so that the community will participate in counseling to form a pious person, possessing religious-spiritual qualities, intellectual intelligence, prosperity, and prosperity in social and economic life. Institutional function in the context of the development of Islamic society, an institution supported by facilities and management that includes the alignment of the interests of the people.

Besides, the Head of the Bengkulu Ministry of Religious Affairs Regional Office, Drs.H. Bustasar.MS., M.Pd Islamic Extension Worker, is one of the partners of the Directorate General of Islamic Community Guidance as well as spearheading the implementation of the task of guiding Muslims to achieve quality and prosperous life both physically and mentally. Its position in the middle of society is critical, and its role is quite large, both because of its knowledge and example in religious practice.

Religious counselors also need to have four main functions attached to them. That is; First, the instructor as a place to obtain information regarding religious life, Second, as a pillar that educates people in line with their respective scriptures, Third, advocating the counselor's role is to defend the group/people from the target of threats and disturbances, and Fourth, the extension as a place to ask, complain about the people to solve problems. "Extension officers must have the capacity of knowledge to provide solutions when there are communities or religious communities who complain."

\section{Education of Moderation}

In the implementation of Education and Training, both the learning process in the classroom, interaction outside the classroom between training participants, participants with the committee, and participants with teaching staff or lecturers must always maintain actions, speech, and discipline. Thus, moderation education has been practiced by the participants and all elements in training. Indeed, some of us, both participant and participant, the participant with committee and participant with teaching staff, have not fully understood the concept of moderation education. Still, in reality, it has been practiced. Moderation education gives messages and impressions to us to understand, understand and establish cooperative relationships to maintain the Ummah's unity (Islamic people). The question is, why? The answer is; because we all live a multicultural life in language, action, culture, and character that are different but are framed by Unity in Diversity in the Unitary State of the Republic of Indonesia. Government Regulations through Joint Ministerial Decrees and Ministry of Religion maintain 
mutual harmony between Interreligious Groups, Intra Religious Groups, and Religious Groups and the Government.

According to Burhani, 2012, education must be directed to the process of independence, not to tame a completely exclusive culture. Because of the complete and intolerant theological perspective or understanding. In turn, it can damage the harmony of religions and eliminate the attitude to respect the truth of other religions. This is where moderate attitudes reap relevance so that a person's perspective will be more inclusive, tolerant, and humanist as a character possessed by moderates.

Azyumardi Azra's opinion is to build harmonious relations between religious communities and create an inclusive religious atmosphere. Then it takes the ability of each religious group. To deepen mutual understanding of other denominations' doctrines and practices as the priority (Azra, 2007).

Education of Moderation teaches us to respect and understand others according to their abilities, so we don't blame each other in discussing, interacting, and socializing. Moderation education leads us not to be extreme, radical, and intolerant. Still, moderation education teaches us to be tolerant and respectful of others' ways, as our role model Rasulullah Muhammad SAW has taught us. Al-Qur'an Surah Al-Baqarah (2): 143;

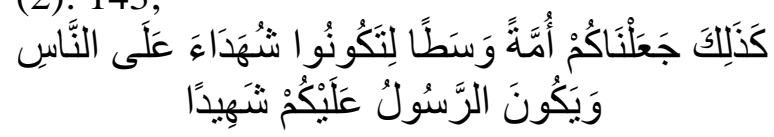

Meaning of that surah; And so (also) we have made you (Muslims) a just and chosen people so that you can be a witness of man's (deeds) and that the Apostle (Muhammad) is a witness to your (deeds) Al-Baqarah (2): 143.

Therefore, to not be trapped in extreme ideology, Islam comes as a mediating religion that instills a moderate attitude in life so that all Muslims do not enter into excessive extremism and feel the most righteous themselves. If we correlate like a referee (fair referee) in a match, the reasonable concept of Islam does not specialize in specific camps and cornering other centers. So, Muslims must be able to do justice and useful, especially religious counselors who carry out counseling in their daily lives without looking at specific camps or ethnicities because Islam comes full of tasamuh to others based on moderate (wasathan) in the souls of Muslims.

Thus Islam can become a religion of rahmatan lilalamin, that faith for all people amidst the turmoil of extreme thought patterns and radicalism that has become widespread lately if it is true that moderate people as wasathan people will appear in themselves the sense of justice, honesty, kindness, and tolerance towards others.

\section{CLOSING}

In carrying out the training, it is expected to involve all elements in Makassar Religious Education and Training. Togetherness and cooperation between the organizers, the implementers/committee, and trainers/educators cooperate in carrying out the education Training. It must also be prepared one month in advance. Our relationship with our fellow human beings must be maintained intact and tightly hold fast to the Islamic foundation that the bearers of Islam have instilled into the land of Indonesia. The moderate attitude upheld by our predecessors must continue to exist in its path. By the way, we maintain Islam's image in the face of the world and protect Islam from extreme groups like people who understand liberal, plural, secular. The emergence of radicals whose poor understanding of Islam is certainly this is all our way to preserve the permanence of Islamic law and practice the concept of moderate (wasahtiyah) in Islam to create a love for others and mutual respect and respect for the diversity and diversity that exists among Muslims, especially in Indonesia. 
The education and training program needs synergy between the organizers, executors/committees, and trainers/instructors to sit together in a preparatory meeting to prepare a learning program in the classroom. Religious instructors must be involved in community activities following their primary duties and functions, the need for the role of stakeholders to improve the quality of human resources, mostly religious counselors in the regions.

\section{BIBLIOGRAPHY}

Aeni, N., Jabu, B., Rahman, M. A., Ismail, H., \& Bin-Tahir, S. Z. (2018). The Students' Needs in Maritime English Class at Ami Aipi Makassar, Indonesia. Journal of Language Teaching and Research,9(6), 1284-1292.

Aeni, N., \& Panggua, S. (2017, July). A classroom action research at the second year students of indonesian maritime academy aipi makassar. In International Conference on Education, Science, Art and Technology (pp. 131-142).

Amri, M., Tahir, S. Z. A. B., \& Ahmad, S. (2017). The implementation of Islamic teaching in multiculturalism society: A case study at pesantren schools in Indonesia. Asian Social Science, 13(6), 125.

Amri, M., Afifuddin, A., \& Bin-Tahir, S. Z. (2018). Religious Pluralism of the Indonesian Traditional Islamic Education Institutions. The Journal of Social Sciences Research, 4(12), 446-450.

Arsyad, U., Putranto, B., Aeni, N., Isnan, W., \& Hasnawir, H. (2019). Analysis of biogeophysics characteristics and discharge of Lompo Riaja Atas river and Lompo Riaja Bawah river, Ralla sub watershed. Jurnal Penelitian Kehutanan Wallacea,8(1), $27-$ 38.

Bin Tahir, S. Z. (2017). Multilingual teaching and learning at Pesantren Schools in Indonesia. Asian EFL Journal, 89, 74-94.

Bin-Tahir, S. Z., Bugis, R., \& Tasiana, R. (2017). Intercultural Communication of a Multicultural Family in Buru Regency. Lingual: Journal of Language and Culture, 4(2), 8-8.
Bin-Tahir, S. Z., Atmowardoyo, H., Dollah, S., \& Rinantanti, Y. (2017). Multilingual learning program: pesantren students' perceptions of the multilingual simultaneous-sequential model. JELE (Journal Of English Language and Education), 3(2), 44-53.

Bin-Tahir, S. Z., Suriaman, A., Hanapi, H., Iye, R., \& Umanailo, M. C. B. (2020). Development of Buru Local Language Conversation Material Based on the CommunicativeInteractive Approach for Elementary School Students. Solid State Technology, 63(2s).

Bin-Tahir, S., Hanapi, H., Mufidah, N., Rahman, A., \& Tuharea, V. U. (2019). Revitalizing The Maluku Local Language In Multilingual Learning Model. INTERNATIONAL JOURNAL OF SCIENTIFIC \& TECHNOLOGY RESEARCH, 8(10).

Bin-Tahir, S. Z., Atmowardoyo, H., Dollah, S., Rinantanti, Y., \& Suriaman, A. (2018). MULTILINGUAL AND MONOMULTILINGUAL STUDENTS'PERFORMANCE IN ENGLISH SPEAKING. Journal of Advanced English Studies, 1(2), 32-38.

Bin-Tahir, S. Z., Hanapi Hanapi, I. H., \& Suriaman, A. (2020). Avoiding Maluku Local Languages Death Through Embedded Multilingual Learning Model: Menghindari Kematian Bahasa Daerah Maluku melalui Model Pembelajaran Embedded Multilingual. Uniqbu Journal of Social Sciences, 1(1), 53-60.

Bin-Tahir, S. Z. (2015). The Power of Love: The Role of Boyfriend in English Language Acquisition.

Bin-Tahir, S. Z., Suriaman, A., \& Rinantanti, Y. (2019). Designing English Syllabus for Multilingual Students at Pesantren Schools. Asian EFL Journal, 23(3.3), 5-27.

Candrasari, R., Fadhillah, N., Praza, R., \& Desiariawati, N. (2018). An Analysis of Culture Value in Adat Bak Poe Teumeureuhom, Hukom Bak Syiah Kuala, qanun Bak Putro Phang, Reusam Bak Binatara. Indian Journal of Public Health Research \& Development, 9(12).

Djunaidi, F. G., Azwan, A. Y. T., Iye, R., \& bin Tahir, S. Z. Decks Range Gola Village Community Begun District Buton District North.

Fadhillah, N., Lubis, M. H., Sinar, T. S., \& Setia, E. (2019). Translation strategies used in Indonesian translation of Acehnese poem 
"Munajat Perempuan Sufi Aceh Pocut di Beutong.". International Journal of Innovation, Creativity and Change,9(4), 172-182.

Khalsiah, R., Fadhillah, N., Praza, R., \& Desiariawati, N. (2018). An Analysis of Culture Value in Adat Bak Poe Teumeureuhom, Hukom Bak Syiah Kuala, qanun Bak Putro Phang, Reusam Bak Binatara. Indian Journal of Public Health, 9(12).

Lubis, M. H., \& Fadhillah, N. (2020). LOOKING FOR TRANSLATION OF MEANING OF WORDS QALA IN MATAN ARBA IN HADITH. Talent Development \& Excellence, 12(1).

Maulina, M. (2019, April). Gender differences in language development, acquisition, comprehension, and production. In PROCEEDINGS OF THE 65th TEFLIN INTERNATIONAL CONFERENCE (Vol. 65, No. 01).

Maulina, M. (2015). The Correlation Among Gender, Languange Learning Strategies, and English Achievment of English Departement Students of Tarbiyah Faculty. Ethical Lingua: Journal of Language Teaching and Literature, 2(1), 27-41.

Maulina, M., \& Rusli, T. I. (2019). Pre-Service Teachers Performance in Implementing Teaching Methods at TEFL Class. Klasikal: Journal of Education, Language Teaching and Science, 1(1), 19-26.

Mufidah, N., Firdaus, U. Z., \& Tahir, S. Z. B. (2018). Model Pengayaan Tutor Bahasa: Studi pre-learning pada Shabahul Lughoh di Ma'had Sunan Ampel Al Aly. Jurnal AtTa'dib Vol, 13(2).

Nadilla, T., Ulfah, A. K., Hayati, H., Midesia, S., \& Puspita, D. (2019, November). The Effect Of Leverage And Earning Per Share On Earning Management (A Study Of Companies Listed In Indonesia Stock Exchange). In ICASI 2019: Proceedings of The 2nd International Conference On Advance And Scientific Innovation, ICASI 2019, 18 July, Banda Aceh, Indonesia (p. 164). European Alliance for Innovation.

Nurlaelah, N., \& Sakkir, G. (2020). Model Pembelajaran Respons Verbal dalam Kemampuan Berbicara. Edumaspul: Jurnal Pendidikan, 4(1), 113-122.

Rinantanti, Y., Bin-Tahir, S. Z., \& Suriaman, A. (2019). The Impact of EFL Senior High
School Teachers' Performance in Papua, Indonesia toward the Students' English Learning Achievement. Asian EFL Journal, 23(3.3), 431-447.

Sakkir, G. (2020). The Effectiveness of Pictures In Enhance Writing Skill of Senior High School Students. Interference: Journal of Language, Literature, and Linguistics, 1(1).

Susiati, S., Masniati, A., \& Iye, R. (2021). Kearifan Lokal Dalam Perilaku Sosial Remaja Di Desa Waimiting Kabupaten Buru. Sang Pencerah: Jurnal Ilmiah Universitas Muhammadiyah Buton, 7(1), 8-23.

Sofie, samsudiin, Iye, R., Tenriawali, A. Y., \& Susiati, S. (2021). IDEOLOGI PRANGGAPAN PAMFLET SOSIALISASI PELESTARIAN LINGKUNGAN DI KABUPATEN BURU. BAHTERA: Jurnal Pendidikan Bahasa Dan Sastra, 20(1), 7283. https://doi.org/10.21009/bahtera.201.07.

Suriaman, A., Bin-Tahir, S. Z., \& Usman, S. (2019). Designing Web-Based English Listening Instruction: An Analysis of Indonesian University Student's Needs. Asian EFL Journl. Vol. 23 (3.3), 28-40.

Saidna Z, B. T., Haryanto, A., Syarifuddin, D., \& Yulini, R. (2017). Multilingual Instructional Model of Pesantren Schools in Indonesia. Journal of Language Teaching and Research, 8(6), 1210-1216.

Sakkir, G., \& Dollah, S. (2019). Measuring students' writing skills using Facebook group application in EFL context. International Journal of Humanities and Innovation (IJHI), 2(3), 6974.

Tahir, S. Z. B., Atmowardoyo, H., \& Dollah, S. (2018). BELAJAR BERBICARA MULTIBAHASA UNTUK SANTRI PESANTREN. Yogyakarta, Deepublish.

TAHIR, S. Z. A. B. (2017). Pengembangan Materi Multibahasa untuk Siswa Pesantren (Doctoral dissertation, Pascasarjana).

Tahir, S. Z. B. (2015). Multilingual Teaching And Learning At Pesantren. 14 Asian EFL Journal Conference.

Tahir, S. Z. A. B. (2017). Pengembangan Materi Multibahasa untuk Siswa Pesantren (Unpublish Doctoral dissertation, Pascasarjana). Universitas Negeri Makassar.

Tahir, S. Z. B., \& Buru, D. U. I. (2012). Humor in "Bukan Empat Mata" Talk Show. Jurnal JUPITER, 5(4), 68-74. 
Tuharea, V. U., Tahir, S. Z. B., Ami, I. S. O., \& Rahman, A. (2020). Buru Language Conservation Through Sustainable Mulok Learning In Buru Regency:(Konservasi Bahasa Buru melalui Pembelajaran Mulok Berkelanjutan di Kabupaten Buru). Uniqbu Journal of Social Sciences, 1(2), 49-55.

Ulfah, A. K. (2014). Implementasi Good Corporate Governance Dalam Meningkatkan Kualitas Pelayanan Pada Pt PLN Wilayah Aceh. Jurnal Administrasi Akuntansi: Program Pascasarjana Unsyiah, 3(3).

Ulfah, A. K. (2018). KINERJA PERSONIL PEMAKAI SISTEM INFORMASI AKUNTANSI SETELAH PELATIHAN SISTEM INFORMASI AKUNTANSI PADA POLDA ACEH. Jurnal Bis-A: Jurnal Bisnis Administrasi, 7(2), 40-46.

Umar, A., Madani, M., Farida, U., Yusriadi, Y., Tamsa, H., Yahya, M., ... \& Misnawati, M. (2019). One-Stop Service Policy as a Bureaucratic Reform in Indonesia. Academy of Strategic Management Journal, 18(2), 112.

Umanailo, M. C. B., Bin-Tahir, S. Z., Mukaddar, M., Kubangun, H., Hamiru, H., Sangadji, M. F., ... \& Yusuf, S. (2018). Economics And Survival Moral Strategies Of The Upland Rice Farmers. In International Conference on Life, Innovation Change and Knowledge (Vol. 1, No. 1).

Wahyuningsih, T., Bugis, M., \& Bin-Tahir, S. Z. (2019). Analysis of the Inequality on Interregional and Inter-time Income Distribution in Indonesia. The Journal of Social Sciences Research, 5(1), 1-8.

Wargadinata, W., Maimunah, I., Tahir, S. Z. B., \& Umanailo, M. (2020). Arabic creative and participative learning: in search of a new way of language learning by "El Jidal Reborn" youth community in Malang. International Journal of Advanced Science and Technology, 2(8s), 4319-4332.

Wijayanto, A. (2021). BUNGA RAMPAI Kolaborasi Multidisiplin Ilmu Dalam Menghadapi Tantangan di Era New Normal.

Yulismayanti, H., Iye, R., \& Susiati, S. Z. B. T. (2020). VARIATIVE METHOD IN IMPROVING STUDENT LEARNING MOTIVATION IN PANDEMIC COVID-19 SITUATIONS. Journal of Critical Reviews, 7(5), 1584-1595.

Yusriadi, Y., Bin-Tahir, S. Z., Farida, U., Sakkir, G., \& Akbar, Z. (2019). Community Perception in the Use of" Songkok Recca"
Hats based on Social Stratification. Anthropos: Jurnal Antropologi Sosial dan Budaya (Journal of Social and Cultural Anthropology), 5(1), 31-39.

Yusriadi, Y., bin Tahir, S. Z., Awaluddin, M., \& Misnawati, M. (2020). Pengentasan Kemiskinan melalui Socialpreneur. Wikrama Parahita: Jurnal Pengabdian Masyarakat, 4(2), 115-120. 